\title{
Al-QAeda's Strategic Gamble: The Sociology of Suicide Bombings in IRAQ
}

Domenico Tosini

\begin{abstract}
This article analyzes the suicide campaign conducted by the Iraqi insurgency since the 2003 US-led invasion. It offers a theoretical framework to identify the factors that explain why only certain armed organizations - in particular Al-Qaeda and its allies - have mounted (even if not exclusively) a specific terrorist campaign against Iraqi civilians (instead of attacking occupying forces), in which they have targeted the Shiite population by perpetrating suicide attacks instead of using other tactics. This issue requires identifying a complex set of preconditions for organizing an armed struggle such as that of the Iraqi insurgency, the two most important being, on one hand, the Sunni insurgents' common capacity for exploiting contingent political and social opportunities after the overthrow of Saddam Hussein, and, on the other, a regular flow of militants, including volunteers to recruit as suicide bombers. At the same time, in accounting for the specificities of Al-Qaeda's armed struggle within the Iraqi insurgency this paper explores three crucial factors underlying its elite members' decisionmaking: the radical opposition of Al-Qaeda and its allies to the new political regime determined by the Anglo-American occupation, combined with the highly asymmetric nature of the fighting between Al-Qaeda and the occupying forces; Al-Qaeda's vigilantism against the Shiites; and, finally, the presumed efficacy of suicide attacks in terms of their military, emotional, and symbolic impacts.

Keywords: Al-Qaeda; asymmetric warfare; axiological rationality; instrumental rationality; insurgency; Iraq; martyrdom; pan-Islamic nationalism; political opportunities; radical Islamism; terrorism; suicide attacks; Sunni extremists; vigilantism.
\end{abstract}

Résumé. L'article analyse la campagne de suicides terroristes de la guérilla iraquienne à partir de 2003, moment de l'invasion par les États-Unis. L'essai présente le cadre théorique des facteurs permettant d'expliquer pourquoi seules certaines organisations armées - en particulier Al-Qaeda et ses alliés - ont entrepris (même si ce n'est pas de façon exclusive) une campagne terroriste spécifique contre les civils iraquiens (au lieu d'attaquer les forces d'occupation); campagne au cours de laquelle ces organisations ont frappé la population chiite par des 
attaques suicides au lieu de recourir à d'autres tactiques. Pour répondre à cette question, il ne fait aucun doute qu'il faut examiner un ensemble complexe de conditions préliminaires sur lesquelles se base l'organisation d'une lutte armée telle que celle de la guérilla iraquienne: d'un côté, en particulier, la capacité qu'ont en commun les guérilleros sunnites d'exploiter les opportunités sociales et politiques qui se sont présentées après la destitution de Saddam Hussein et, de l'autre, le flux régulier de militants, y compris des volontaires recrutés comme auteurs d'attentats suicides. En même temps, afin d'expliquer les spécificités de la lutte armée d'Al-Qaeda dans le contexte de la guérilla iraquienne, cet article explore les trois facteurs fondamentaux qui sont à la base des décisions de ses leaders: l'opposition radicale d'Al-Qaeda et de ses alliés au nouveau régime politique résultant de l'occupation anglo-américaine, associée à la nature fortement asymétrique du conflit entre Al-Qaeda et les forces d'occupation; le vigilantisme d'Al-Qaeda vis-à-vis des chiites; et, enfin, l'efficacité présumée des attaques suicides du point de vue militaire, émotif et symbolique.

Mots clé: Al-Qaeda; attaques suicides; Sunnites extrémistes; guerre asymétrique; guérilla; Iraq; Islamisme radical; martyre; nationalisme panislamiste; opportunités politiques; rationalité axiologique; rationalité instrumentale; terrorisme; vigilantisme.

\section{INTRODUCTION}

Since the overthrow of Saddam Hussein's regime following the 2003 Anglo-American invasion, Iraq has become a theatre of a asymmetric warfare conducted by a multifaceted Sunni insurgency (Baram 2005; Chehad 2005; Hashim 2006; Kohlmann 2007; Robinson 2007). Particularly striking is the wave of mass casualty attacks against Iraqi civilians, frequently involving the use of suicide bombers. We define suicide attacks as violent acts whose execution requires the death of at least one individual, namely one or more attackers (Bloom 2005; Gambetta 2006; Hafez 2007; Moghadam 2008; Pape 2006; Pedahzur 2005; Reuter 2004). The number of suicide attacks perpetrated by armed groups has increased over the last three decades, with an estimated 2,406 incidents associated with several campaigns between December 1981 and the end of December 2008, responsible for between 24,383 and 26,408 deaths. ${ }^{1}$

1. Data consist of the entire population of those attacks that have been executed by at least one attacker killing herself or himself between December 1981 and the end of December 2008. We include all single episodes (provided with sufficient description) mentioned in the following sources: 1) Gambetta - Tzvetkova Suicide Attacks Dataset, Nuffield College, Oxford (http://www.nuff.ox.ac.uk/projects/datalibrary/holdings datasets.aspx), which covers suicide attacks (except those of Chechen separatists and using a sample of Iraqi suicide attacks) occurring worldwide between 1981 and January 2006 (see Gambetta 2006); 2) Pape (2006), which includes suicide attacks executed worldwide from December 1981 to December 2003, and up to December 2005 for 
Of those, 1,336 attacks have been perpetrated by Iraqi insurgents since the military invasion of Iraq in March 2003, causing between 12,447 and 13,403 deaths, and accounting for about $56 \%$ of incidents and $51 \%$ of fatalities, respectively, caused by all suicide attack campaigns since the 1980s. A high percentage of the targets of those suicide bombers have been the new Iraqi forces and defenceless civilians, in particular Shiites (Hafez [2007] estimates 44\% and 23\%, respectively, compared with $15 \%$ made up of coalition forces). Data from Worldwide Incidents Tracking System (http://wits.nctc.gov) show that, between January 2004 and December 2008 , civilians were more than $70 \%$ of those killed $(11,604)$ by suicide attacks in Iraq.

A recurrent argument concerning suicide attacks is that armed groups resorting to this tactic are generally engaged in a campaign for the liberation or independence of a territory, that is, for nationalist purposes (Pape 2006; see also Brym 2008). To some extent, our data support this hypothesis, which accounts for the suicide attack waves of Hezbollah's campaign in Lebanon in the 1980s against the US, France, and Israel (Kramer 1998; Ranstorp 1997; Reuter 2004); the Liberation Tigers of Tamil Eelam's struggle for Tamil independence since 1987 (Hopgood 2006); Hamas and other Palestinian organizations against Israel (Levitt 2006; Ricolfi 2006); the Kurdistan Workers' Party's campaign for the independence of Kurdistan; the Chechen insurgency for secession from Russia; and the struggle by the Kashmiri separatists such as Jaish-eMuhammad and Lashkar-e-Toiba against India (for an overview on all these campaigns, see Hassan 2008). Such a nationalist theory can also account to some extent for Al-Qaeda and its affiliates (Gunaratna 2002), notably some Iraqi Sunni insurgents such as Al-Qaeda in Iraq (AQI) and Ansar Al-Sunnah, and its allies such as the Taliban in Afghanistan, insofar as their immediate goal has been the liberation of Muslim countries from the US-led occupation (Cordesman 2008; Goodwin 2006a; 2006b; Hafez 2007; Hashim 2006; Karam 2007; Moghadam 2008; Nance 2007; Pape 2006; Riedel 2008).

Iraq only; 3) an updated version (accessed in January 2006) of the dataset maintained by the University of Haifa (formerly published in Pedahzur 2005), which covered suicide attacks perpetrated worldwide between December 1981 and June 2005 (the author thanks Ami Pedahzur and Arie Perliger for the access to this dataset). All these data were subsequently integrated by including all single suicide attacks identified by further databases: 4) the Global Terrorism Database (GTD2) (http://209.232.239.37/ gtd2) (accessed in October 2008), which covered data on terrorist incidents worldwide since January 1998 (updated through December 2004); and 5) The Worldwide Incidents Tracking System (WITS) at the National Counterterrorism Center (http://wits. nctc.gov) (accessed in October 2008 for suicide attacks between January 2004 and June 2008, and in April 2009 for suicide attacks between July 2008 and December 2008), which covered terrorist incidents occurring worldwide since January 2004 (updated through December 2008). 
That said, three questions related to the decision-making of certain organizations' elite members within the Iraqi insurgency remain unanswered: (1) why only certain armed groups - in particular AQI and its allies - within the Iraqi insurgency have mounted (even if not exclusively) a specific terrorist ${ }^{2}$ campaign against Iraqi civilians (instead of attacking occupying forces), in which (2) they have targeted the Shiite population, (3) by resorting to suicide attacks instead of other tactics. These questions certainly require identifying a complex set of conditions for organizing an armed struggle such as that of the Iraqi insurgency, the most important being, on one hand, the Sunni insurgents' common capacity for exploiting contingent political and social opportunities after the overthrow of Saddam Hussein ("Sunni Insurgents' Political Opportunities"), and, on the other hand, a regular flow of militants, including volunteers to recruit as suicide bombers ("Suicide Bombers in Iraq: Profiles and Motivations"). In accounting for the specificities of AQI's armed struggle within the Iraqi insurgency the following elements are also crucial factors underlying its elite members' decision-making: the radical opposition of AQI and its allies to the new political regime established after the Anglo-American occupation of Iraq, combined with the highly asymmetric nature of the fighting between AQI and the occupying forces ("Al-Qaeda's Political Position and Asymmetric Warfare"); AQI's vigilantism against the Shiites ("Al-Qaeda's Vigilantism against the Shiites"); and, finally, the presumed efficacy of suicide attacks in terms of their military, emotional, and symbolic impacts ("The Instrumental Rationality of Suicide Attacks").

\section{Sunni Insurgents' Political Opportunities}

The suicide campaign conducted by AQI and its allies in Iraq presupposes certain conditions. This section focuses on the fact that all terrorist campaigns exploit a series of political opportunities: in this case, contingencies associated with the political and cultural environment following the US-led invasion of Iraq (Hafez 2007; for empirical cases of other armed groups, see della Porta 1995; Goodwin 2001). ${ }^{3}$ For example, variations in the frequency of suicide attacks (see Graph below) are dependent on certain political and military events (Cordesman 2008:576,

2. We define terrorism as the use of violence against civilians (and personnel not engaged in combat operations) by nonstate entities for political purposes (see Tosini 2007a; 2007b).

3. In the next section, we will examine a second condition: the recruitment of militants, including those who volunteer as suicide attackers. 


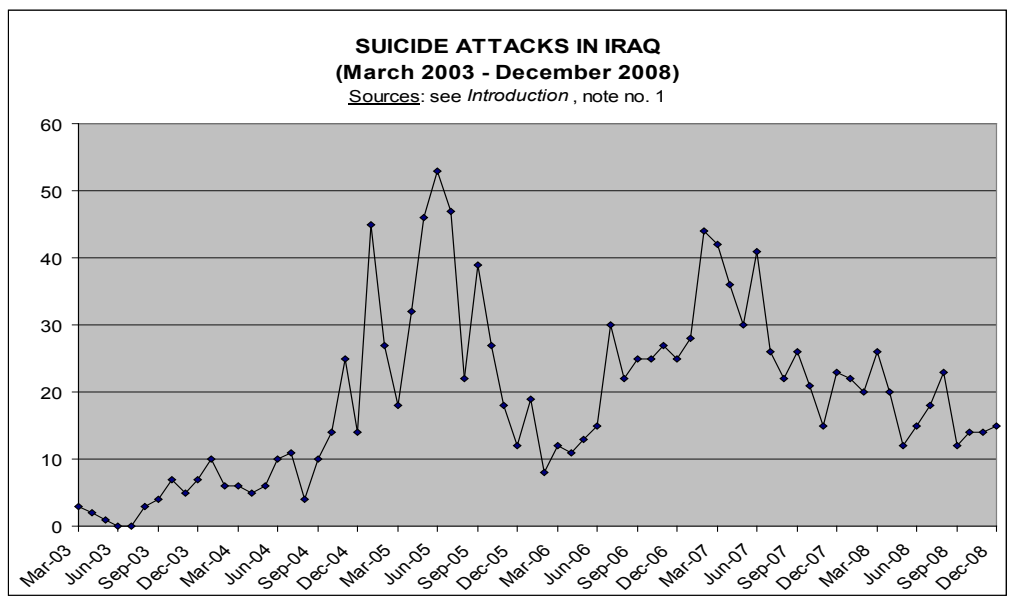

582; Nance 2007:Chapters 6 and 8; Riedel 2008:Chapter 5; cf. Hafez 2007:Chapter 3; Hashim 2006:Chapter 3).

As in other insurgencies, changes in the intensity of attacks are related to the reactions of Sunni armed groups, such as AQI, to the American intervention and to the political stance of other ethnic and religious communities such as the Kurds and Shiite Arabs. In particular, certain escalations in the use of bombings should be seen as Sunni insurgents' increased efforts to enhance their support from the Sunni community, as well as their power to influence the Iraqi political arena, by capitalizing on the negative consequences that Sunni Arabs have suffered since the US-led invasion. This use of political violence is evidence of the strategic nature and instrumental rationality of Sunni terrorist organizations and of Iraqi (suicide) terrorism (Hafez 2007; Moghadam 2008; Pape $2003 ; 2006)$. The following analysis is based on the occupation's impact on the Sunni Arabs' power.

The political position and privileges that especially Sunni Arabs enjoyed under Saddam Hussein were, first of all, challenged by two provisions adopted in May 2003 by the US-led Coalition Provisional Authority, headed by Paul Bremer: the De-Baathification of Iraq, which established the expulsion of former members of the Baath party from institutions of the new political regime; and the Dissolution of Entities, which ordered and entailed the termination of Saddam Hussein's army and armed forces (International Crisis Group [ICG] 2006a; 2006b). As stated by former US ambassador Peter W. Galbraith,

Bremer's high-handedness created unnecessary enemies. Since Saddam's army had already vanished (as Bremer explained later to justify his de- 
cree), there was no need to dissolve it. Sunni officers saw the decree as insulting and arrogant, and there is no doubt that the decree - not just the fact of not recalling the army - added to Sunni bitterness and helped drive men with weapons, and knowledge of how to use them, to the insurgency. The de-Baathification order was both too extreme and interfered with the urgent short-term goal of reconstructing Iraq's bureaucracy. Almost all of Iraq's top civil servants were members of the Baath party and therefore were banned from their old positions. As a result, from mid-May 2003, not only were Iraq's government offices largely empty shells without files and furniture but the experienced managers had all been fired. The decree also affected tens of thousands of others, including teachers and doctors, who joined the Baath party simply to advance their careers. (Galbraith 2008:55)

A further challenge came in July 2003, when the Coalition Provisional Authority set up the Iraqi Governing Council, consisting of 25 Iraqi leaders with the task of fixing the most urgent issues in the new political context. Its activity resulted in the constitutional project of March 2004 known as Transitional Administrative Law. Both the appointment of only five Sunni Arab representatives on the Iraqi Governing Council and the increasing attempts by Shiite Arabs and Kurds to enforce those two provisions were, for the Sunni Arabs, clear signals of a conspiracy against them (Cordesman 2008:Chapters 3 and 4; Hashim 2006:Chapter 2; Jackson 2006). Several suicide attacks followed: among others, the 19 August 2003 attack against the UN headquarters in Baghdad (22-23 deaths), the August 29 attack against a Shiite mosque in Najaf (95 deaths), the October 27 attack against the Red Cross headquarters in Baghdad and three stations of the new Iraqi police (34-35 deaths), and, finally, the November 12 attack against the Italian Carabinieri in Nasiriyah (26-31 deaths).

The incidents between May and July 2004 were linked to the US handover of power to the interim government led by a Shiite leader, Ayad Allawi, at the end of June 2004. For the Sunni Arab minority, this was more evidence of the Shiites' political ascent and of its own exclusion and marginalization. The handover was preceded, on June 24 , by a suicide attack in Mosul against two police stations, a hospital, and a police academy, claiming a total of about 60 deaths. Other suicide attacks followed, such as one on July 28 against a police station in Baqubah (68-70 deaths) and four suicide car bombs of November 6 in Samarra (23-42 deaths).

The wave of suicide attacks between September 2004 and January 2005 was contingent on the election of the assembly to draft the new constitution. Numerous politicians were assassinated in the weeks preceding 
the January 30th election. Between December 2004 and January 2005, there were 59 suicide attacks, claiming 428-498 deaths. The escalation of attacks between April and August/September 2005 were related to the nomination of Kurdish leader Jalal Talabani as President and the Shiite Ibrahim Jaafari as Prime Minister in April 2005 and the support for the draft constitution by the new government. In 2005 AQI made major efforts to hit Shiite civilians and the new Iraqi security forces (Cordesman 2008:Chapter 6). On 18 February 2005, for example, during the Ashura commemoration, two mosques in Baghdad were targeted with a coordinated attack by several suicide bombers, claiming a total of 14-38 deaths. Likewise, on March 3 a suicide attack against a mosque in Mosul killed 53 civilians.

The increase in attacks during the second half of 2006 was a reaction to the US-led assassination (June 2006) of AQI's leader, Abu Musab $\mathrm{Al}-Z a r q a w i$, and the subsequent security provisions of the new Prime Minister Nuri Al-Maliki, particularly an amnesty for insurgents. The final escalation of suicide attacks between January and June/July 2007 was a response to the increase of US troops (the "surge") established by the Bush administration. Since then, and especially since the summer of 2007, the insurgency has been in retreat, while there has been a marked decrease in the frequency of suicide and other high-profile attacks (Cordesman 2008).

A crucial contribution to this containment of AQI's insurgency has been the role of the Al-Sahawa (Awakening), a movement established in 2006, when several Sunni tribal leaders created their own militias sponsored by the US army. This reaction by the Sunni community depended on what Sunni tribal leaders and members of their tribes view as AQI's brutality and fanaticism and its interference in tribal economic and political interests (cf. González 2009). In the long term, AQI tried to impose its own fundamentalist view of society and was indifferent to the social and economic needs of Sunnis. This clearly distinguishes AQI from other jihadist groups such as Hezbollah and Hamas, more dedicated to assisting their communities (Levitt 2006). As a consequence, Sunnis, who originally established some form of alliance with AQI, have become increasingly alienated from the Islamists and supportive of American counterinsurgency (Galbraith 2008).

AQI responded to this challenge by launching a series of reprisals against key figures of Al-Sahawa, such as the suicide attacks of 25 June 2007, in Baghdad (claiming 12 deaths, including several tribal leaders of Al-Sahawa) and the September 13 assassination of Abdul Sattar Abu Risha, one of the US allies and leader of the Anbar Al-Sahawa, as well as numerous similar attacks in the following months (Paley 2008). None- 
theless, due to American military superiority and the economic support provided to the Sunni militias by the US-led coalition, AQI's escalation of violence against Sunnis has been unable to prevent further defections. AQI is losing the collaboration it needs to maintain strongholds within Sunni areas and prepare new insurgent attacks. This explains the decrease in the number of suicide attacks since the summer of 2007 (cf. González 2009).

\section{Suicide Bombers in IraQ: Profiles and Motivations}

The second condition for organizing the Iraqi suicide campaign has been the availability of fighters as bomber recruits. Investigations of their profiles and motivations are hampered by difficulties obtaining adequate biographical documents. The clandestine nature of insurgents creates numerous obstacles to understanding the process of the radicalization, recruitment, and training of militants. A lack of terrorist communiqués related to Iraqi suicide bombings poses additional challenges; of all the suicide attacks in Iraq up to February 2007, 75\% were unclaimed (Ayers 2008). As a result, for most Iraqi suicide attacks, no information is available either about the organizations behind them or about the fighters delivered as suicide bombers. They remain "ghost martyrs," complicating efforts to collect empirical evidence of their motivations. These fragmented research sources make all theoretical statements on suicide bombers in Iraq merely hypothetical.

Most inquiries estimate that the majority of suicide bombers in Iraq have been foreign fighters, especially from Arab countries of North Africa and the Middle East (Cordesman 2008; Combating Terrorism Center [CTC] 2007, 2008; Hafez 2007; Moghadam 2008). In March 2005, Reuven Paz (2005) examined information about 154 Arab fighters killed in Iraq and identified as "martyrs" by jihadist web forums. Of them, 33 carried out suicide attacks. In both cases more than $60 \%$ were Saudis. Relying on data collected by the Saudi National Security Assessment Project, in September 2005 Nawaf Obaid and Anthony Cordesman reported an estimate of 3,000 foreign fighters in Iraq, with Algerians constituting the largest contingent (20\%) (Obaid and Cordesman 2005). In February 2007, Thomas Hegghammer (2007) published a report based on the analysis of 205 biographies of Saudis who died in Iraq between 2003 and 2005, all young males who were on average 23 years old in 
2003. ${ }^{4}$ The fighters' socioeconomic profiles reveal that some were very poor, while others came from rich and privileged families. Many were highly educated: of the 16 for whom education level is known 14 had some higher education, one even had a doctorate. There is also information about the occupation of 26 individuals, the majority (14) being students. Geographic and tribal origins show the relatively large presence of "northerners," suggesting that geographic proximity to Iraq influenced recruitment. At the same time, tribal loyalties might have been a recruitment factor, since there are tribes present on both sides of the border (Hegghammer 2007:13).

In December 2007, the Combating Terrorism Center at West Point (CTC 2007) published an analysis of nearly 700 records (known as the Sinjar Records) of foreign nationals that entered Iraq between August

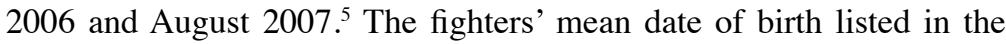
Sinjar Records was 1982. The average age was 24-25 (the median 21$22),{ }^{6}$ while, of the 156 fighters that specified their occupation or profession, $42 \%$ were students. There were twenty-one countries mentioned as the origin of one or more fighters. Again, Saudis contributed the highest number of fighters (237) - 41\% of the 576 fighters that listed their nationality. Libya contributed the second highest percentage of fighters (about 19\%). The other most common countries were Syria, Yemen, and Algeria. Two were from France, one from Britain, and one from Sweden. However, in spite of a lower number of Libyans than Saudis, Libya contributed far more fighters per capita than any other nationality. The Sinjar Records show that, at 18.55 fighters per one million people, Libya was supplying fighters at a rate twice that of Saudi Arabia. Particularly interesting to the analysis of the Iraqi suicide campaign is that $56 \%$ of the 376 fighters that indicated their "work" in Iraq were to be suicide bombers (istishhadi). Data confirm that the plurality of suicide attack-

4. According to the author, "this relatively low average indicates that the Saudis in Iraq represent a relatively new generation of mujahideen. Indeed, only 9 of the 205 are known to have had previous combat experience from Afghanistan, Bosnia, or elsewhere. This shows that recruitment to Iraq is a distinct and spontaneous phenomenon whose relation to the old al-Qaida networks is only peripheral. However, anecdotal evidence suggests that some had connections with " "al-Qaida on the Arabian Peninsula' and came to Iraq to escape from the Saudi security services" (Hegghammer 2007:12).

5. Data were obtained from US military officials in November 2007 and refer to information collected by AQI and Iraqi affiliates, first the Mujahideen Shura Council and then the Islamic State of Iraq. The records were captured by coalition forces in October 2007 in a raid near Sinjar, along Iraq's Syrian border. All statistical information cited in this paper is based on a new report of the Combating Terrorism Center (CTC 2008), in which the accuracy of the 2007 data has been improved (CTC 2007).

6. This suggests once again that the most of these fighters were first-time militants rather than veterans of other Islamist campaigns (such as the often cited Afghan anti-Soviet jihad of 1980s). 
ers entering Iraq during the period covered by the Sinjar Records were Saudi (70 fighters), corresponding to $47 \%$ of the total number of Saudi fighters. The same Sinjar Records show that Saudi fighters are not more likely than those from other countries to be recruited as suicide attackers. Libyan (51) and Moroccan (22) fighters that referred to their "work" were much more likely to be enlisted as suicide bombers, corresponding to $85 \%$ of the total number of Libyan fighters and $91 \%$ of the Moroccan fighters, respectively.

That said, the motivations of fighters in general and of suicide bombers in particular remain an enigma. We will present a typology (in Weber's parlance) of the main motivational factors underlying militants' personal decisions to volunteer as suicide attackers in the Iraqi terrorist campaign. First, emotional elements, especially anger, outrage, and humiliation certainly played a role. Narratives found in martyrdom videos sometimes reflect such affective motivations, resulting in desire for revenge. An example is the video by the AQI-led Mujahideen Shura Council in Iraq, aired in February 2006 and titled Fatima's Fiancé. It shows Abu Muawiyah Al-Shimali, a Saudi suicide bomber, whose operation is represented as a reaction to an alleged letter of December 2004 sent by a female detainee at Abu Ghraib prison, named Fatima. In the letter, Fatima called on the mujahedeen to come to rescue all the female prisoners who were subjected to daily rape, torture, and humiliation by the "sons of the pigs and the monkeys" (probably referring to Jews). After describing the torture and humiliation, she invokes the insurgents to save the prisoners:

Remain faithful to Allah. Leave their tanks and planes, come to us in Abu Ghraib prison, and kill us along with them. Destroy us along with them. Don't leave us to them. Kill us along with them, and then maybe we will have peace. (Al-Qaeda in Iraq 2006a)

Then a script in the video states:

Like all of us, Abu Muawiyah Al-Shimali read the letter written by the sister in Abu Ghraib prison before she was martyred. He could not calm down, and resolved to avenge her death, and the deaths of all free Muslim women. He could find nothing more precious than his own soul to sacrifice for the sake of Allah, and to redeem the honour of his sisters. He asked Allah to accept him as a martyr, and to marry him to this young woman. (Al-Qaeda in Iraq 2006a)

Reference to the outrage inspired by the letter and a desire for revenge is also made in the final statement by Abu Muawiyah himself: 
America, the only things awaiting you here are these buttons [referring to the detonator]. I have my bag with me. In it, I have TNT, and a gas container next to me. The land is calling me, leading me to Paradise. The youth who follow religion do not care about the rulers. Oh Bush, you despicable son of a despicable man, you will bow your head. We've already destroyed the [World Trade Center] tower, and we will make you bow your head.... Allah, marry me to the sister Fatima, who was killed in Abu Ghraib, and whose honour was defiled by the tyrants and apostates, the offspring of apes and pigs. (Al-Qaeda in Iraq 2006a)

Second, specific egoistic interests should not be excluded from analysis of the motivations of suicide bombers. Previous cases of suicide bombers reveal that a suicide mission can also be selected as a way, for example, to overcome circumstances of social marginalization, anomie, a lack of self-esteem due to past wrongdoings (Khosrokhavar 2005; Pedazhur 2005), and to search for comradeship (Sageman 2004; 2008; Wintrobe 2006). Here, taking part in a suicide mission, despite the cost of the death, is viewed as an opportunity to obtain social consideration and reputation among comrades. This is tantamount to an elevation of status, which means that suicide missions are here instrumental actions: behaviours motivated by a rational choice. From this perspective, referring to the much-studied cases of Palestinian bombers, Luca Ricolfi argues:

[A] martyr is not an anonymous militant who carries out a mission decided by his organization, and whose name may remain unknown. A martyr is a volunteer who has been selected, who leaves a last will and testament (normally a videotape), and who will be remembered by his fellow countrymen through photographs, posters, murals, and plaques, exhibited in public places. In other words, one of the rewards of a martyr is fame, the prestige that the operation will bring to his name and his family. While a militant may die anonymously, and thus sacrifice himself twice, a martyr pays 'only' with his life but obtains fame and recognition in return. The symbolic calculation may explain why certain people may prefer to choose martyrdom directly over militancy of a more traditional kind. This type of motivation reveals an individualistic aspect of martyr operations, and help us understand why such operations manage to attract individuals lacking religious motivations (secular suicide missions). (Ricolfi 2006:113-114)

However, the fact that the majority of suicide bombers within the Iraqi insurgency have remained anonymous or "ghost martyrs," (Ayers 2008) calls into question the hypothesis of the personal search for social consideration as the fundamental driving motivation for sacrifice. The 
same can be said of the desire to attain paradise. Rather, both benefits should be analyzed as facilitating factors.

... like the knowledge that one's relatives will be financially taken care of after one is dead, the belief in some kind of afterlife may attenuate the psychological costs of commitment. [R]ather than offering a positive motivation the religious and financial expectations might have the disinhibitory effect of lifting some of the normative constraints against suicide missions. (Elster 2006:243)

Third, this suggests the necessity of taking into account other motivations, such as the strength of certain ideological convictions underlying militancy and participation in highly risky missions. Devotion to political and religious values, in particular, played a crucial role for those Muslims militants who volunteered for Iraqi suicide missions. Field research and interviews offer some empirical evidence. Hegghammer (2007), for example, emphasizes the devotion of young Saudis to the ideal of defence of the Islamic nation (ummah), which can be traced back to the 1960s when King Faisal propagandized Islamic solidarity (al-tadamun al-islami) as a counterweight to Nasser's Arab nationalism. In the 1980s the Saudi state actively promoted such a solidarity to mobilize fighters during the Afghan campaign. This ideology constitutes a motivational framing (in Snow's and Byrd's parlance [2007]) that can be conceptualized as supra-nationalism or pan-Islamic nationalism insofar as it calls for the duty of jihad in defence of all oppressed Muslim countries. This kind of nationalism has been crucial in driving generations of fighters to take part in the anti-Soviet campaign in Afghanistan, and in jihadist campaigns such as those in Bosnia, Chechnya, more recently in Iraq, and once again in Afghanistan (Hegghammer 2007:8-10). Pan-Islamic nationalism is a recurrent motivational factor referred to in videos of foreign fighters in Iraq. For example, in May 2006 the Mujahideen Shura Council released an interview with two alleged militants, ${ }^{7}$ one of them declaring:

By God, we did not leave Saudi Arabia to escape from reality. On the contrary, we left [Saudi Arabia] to stand side-by-side with our brothers in Iraq. And we are full of sadness when we witness our sisters being humiliated. And our brothers in Fallujah are being killed on a daily basis. We came to bring victory for the religion of Allah, and to stand against the infidel occupation of Iraq that spread corruption and tyranny in the land. (Nine Eleven Finding Answers [NEFA] Foundation 2006)

7. The two men have subsequently been identified as 24-year old Chadian national Abu Hassan Al-Makki (aka Manour Muhammed Yousef) and 23-year old Chadian national Abu Nasser Al-Chadi (aka Othman Mohammed Hassan Kourani) (see NEFA 2006). 
A similar devotion has been documented by a series of interviews conducted in Zarqa, Jordan, by Souad Mekhennet and Michael Moss. Abu Ibrahim, a 24-year-old who left Jordan in October 2005 to volunteer for a suicide mission in Iraq with other comrades (but was arrested before committing it), states:

I am happy for them but I cry for myself because I couldn't do it yet.... I want to spread the roots of God on this earth and free the land of occupiers. I don't love anything in this world. What I care about is fighting.... The sheik [Abu Musab All-Zarqawi], he was a hero. (cited in Mekhennet and Moss 2008)

According to an Islamist community leader interviewed by Mekhennet and Moss,

... most of the young people here in Zarqa are very religious.... And when they see the news and what is going on in the Islamic countries, they themselves feel that they have to go to fight jihad. Today, you don't need anyone to tell the young men that they should go to jihad. They themselves want to be martyrs. (cited in Mekhennet and Moss 2008)

Libyans fighting in Iraq have also been driven by pan-Islamic nationalist sentiments and search for martyrdom. In his report from Darnah, Kevin Peraino uncovers complex constellations of factors underlying participation in Iraqi insurgency, such as unemployment, desperation, or personal trauma. However, an additional, crucial influence might be attributed to the political narrative linked to the history of the Libyan anticolonial resistance against Italians between the 1910s and 1930s:

Local resistance to the occupation was strongest in the rocky hills near Darnah, but even there it was ultimately crushed. From its dust, a homegrown tradition of Islamic martyrdom emerged. The local mythology is so pervasive that it guides even the town's most senior officials. On my second day in Darnah, I stopped by the office of Saddik Afdel, the cochairman of the town's People's Committee - the Libyan equivalent of a mayor. At first he denied that his town was sending a significant number of its young men to Iraq.... [H]e eventually conceded. "If this number is true, it's very bad. It's bad for politics. But it's not bad for Muslims to do their duty. America said that this war is for freedom. And it's not. What we see on Al-Jazeera is not what we've been told by the Americans. I can't stop them from going. What we've been taught by the Qur'an is jihad." When I asked about the town's history of rebellious militants, Afdel couldn't suppress a grin. "Those are the people who used to stand up and fight for their land," he told me. "We have to remember them...." Today the cult of Omar al-Mukhtar [who led a guerrilla war against Italians] is visible 
everywhere in Darnah: on posters, billboards, stickers on car windshields. His face may be more ubiquitous even than Kaddafi's. Bootleg copies of "Lion of the Desert" are brisk sellers in local souks.... Hinid [a Darnah' resident] showed me a portrait of Mukhtar. He said he painted it on the night of Saddam Hussein's execution. Hinid had watched the hanging on Al-Jazeera. The sad eyes in his painting of Mukhtar, Hinid explained, are actually Saddam's. It isn't difficult to see how the Iraqi dictator might provide Darnah residents with a modern-day stand-in for their martyred hero. "We all love [Saddam] here," Hinid told me. (Peraino 2008)

Such testimonies show that pan-Islamic nationalism and aspiration to martyrdom form a mixture of motivations underlying foreign fighters' participation in the Iraqi insurgency. The defence of the Islamic nation from occupiers constitutes one of the most important objectives. This constitutes a form of instrumental rationality, insofar as suicide bombers view their actions as an adequate means to compel Americans and their allies to withdraw from Muslim countries such as Iraq. This also presumes (in the same manner as Al-Qaeda's elite members) a high efficacy of terrorist tactics in general and suicide missions in particular, in comparison with other tactics. Because such a calculation serves a collective cause, these actions should be conceptualized as altruistic suicide (Durkheim 2006). However, what mainly emerges from a plurality of fighters' statements is a form of axiological rationality, combined with other personal aspirations to social consideration. Here, axiological rationality (or Wertrationalität, in Weber's parlance) indicates an absolute commitment to values such as pan-Islamic nationalism and martyrdom (cf. Boudon 2003; 2007; Brym 2008; 2009). This means that, under certain circumstances such as military occupations of Muslim countries, any pious Muslim will have a duty to answer to and conform his behaviour to a call for jihad, even at the cost of his life and regardless of the consequences of his actions (Tosini 2009). As is clarified below, these values have been frequently exploited by elite members of Al-Qaeda and used as crucial components of their propaganda machine to recruit fighters, particularly suicide bombers.

\section{Al-Qaeda's Political Position and Asymmetric Warfare}

The political contingencies discussed in the section on Sunni insurgents' political opportunities and the availability of suicide bombers (whatever their motivations) analyzed in the section of suicide bombers in Iraq partially account for the emergence and strengthening of the Iraqi insurgency and, in particular, for the use of suicide attacks. However, to an- 
swer the first of the three questions presented here, other factors should be examined that focus on the decision-making of insurgents' elite members: why only certain armed groups - in particular AQI and its allies - within the Iraqi insurgency have mounted (even if not exclusively) $a$ terrorist campaign against Iraqi civilians, instead of attacking occupying (military) forces? To approach this question, this section examines the specificities of AQI's political position and strategy with respect to the US-led occupation of Iraq.

The Iraqi insurgency has been mainly Sunni Arab, despite the fact that Sunni Arabs only consist of about $17 \%$ of the Iraqi population. Both Sunni Kurds and Shiite Arabs - accounting for around 18\% and 60\% of Iraqis, respectively - were only marginally involved (Hashim 2009). In the Sunni insurgency, AQI's members were a minority. There were two larger components. The first consisted of secular organizations former members of the Baath party, and of the army and security forces of Saddam Hussein, including not only the regular army and the Republican Guard, but also such paramilitary organizations as the Saddam Fedayeen. After the 2003 invasion, this group was reorganized under the command of former Iraqi officials based in Syria, adopting cover names such as Majlis Watami Al-Muqawamah Al-Iraq (National Council of the Iraqi Resistance) and Qaidat Al-Whidah Al-Mujahideen (Mujahideen Central Command). They also used propagandistic labels such as Jaish Al-Mujahideen (Mujahideen Army) and Jaish Al-Muhammad (Muhammad Army), operating in Iraq through countless regional cells such as Hizb Al-Awda (Party of Return) and Al-Muqawamah Wal-Tahrir fi Iraq (Resistance and Liberation in Iraq) (Nance 2007:99-109; cf. Hafez 2007:Chapter 1). Based on the number of attacks claimed by and attributed to such armed groups in October 2006, it is estimated that they consisted of about 30,000 active militants and 60,000 active supporters, or about $80-85 \%$ of the Iraqi Sunni insurgency (Nance 2007:Chapter 1, $99 \mathrm{ff}, 137 \mathrm{ff})$. The second large component of the insurgency consisted of Islamist organizations, such as Al-Jaish Al-Islami fi Al-Iraq (Islamic Army of Iraq), Ansar Al-Sunnah (Partisans of the Sunnah) and Kataib Thawrat Al-Ishrin (Battalions of the 1920 Revolution) - aka Harakat Al-Muqawamah Al-Islamiyyah fi Iraq (Islamic Resistance Movements in Iraq) - and, finally, AQI. All these groups were inspired by the ideology of armed jihad.

According to the same estimate concerning the state of the Sunni insurgency in October 2006, AQI had a total of about 2,000 members, corresponding to about $2-5 \%$ of the insurgency. Despite its small size, AQI was one of the most violent organizations within the Sunni insurgency, as demonstrated by its mass casualty attacks against civilians. 
This mainly stems from its radical opposition to the American-led occupation of Iraq and its puppet regime. As stated by Cordesman,

Experts long pointed out that one of the key differences between Islamist extremist terrorism and previous forms of terrorism was that they are not seeking to negotiate with those they terrorize, but rather to create conditions that could drive the West out of the Middle East, undermine secular and moderate regimes in the Arab and Islamic worlds, and establish the conditions under which they can create "Islamic" states according to their own ideas of "Puritanism." This was why it served the purposes of Islamist extremists, as well as some of the more focused opponents of the United States and the West, to create mass casualties and to carry out major strikes, or carry out executions and beheadings, even if the result was to provoke hostility and anger. The goal of Osama Bin Laden and those like him was not to persuade the United States or the West; it was rather to alienate them from the Islamic and Arab worlds so that the forces of secularism in the region would be sharply undermined, and the Western influence could be controlled or eliminated. The goals of most Iraqi insurgents was narrower - drive the United States and its allies out of Iraq - but involved many of the same methods. (Cordesman 2008:672; see also Hafez 2007:Chapter 2; Hashim 2006; Kohlmann 2007; Moghadam 2008; Nance 2007)

Compared with the other Islamist organizations within the Iraqi insurgency, AQI shows additional, specific features. Its leaders have been non-Iraqi nationals with strong ties to the original nucleus of Al-Qaeda. The political agenda of AQI maintains a transnational mark inspired by the most radical version of the armed jihad at the centre of certain sectors of Sunni radicalism (Cook 2005; Cook and Allison 2007; Campanini 2008; Campanini and Mezran 2007; Esposito 2002; Guolo 2002; Guolo and Pace 1998). Furthermore, AQI does not conceive of the Iraqi insurgency as a purely local enterprise, but as part of a broader campaign aimed at defending the Islamic nation from foreign aggression (Hegghammer 2007; Pape 2006; Tosini 2007a; 2007b; cf. Hafez 2007; Pedahzur 2005; Riedel 2008; Sageman 2004; 2008). The occupation of Iraq is perceived as the umpteenth attempt by the US and its allies to occupy and subordinate the Muslim countries, as frequently stated by Osama Bin Laden (Bin Laden 1996; 2006; see Pape 2006:Chapter 7; cf. Gunaratna 2002; Sageman 2004).

To offer a comprehensive description of Al-Qaeda it is necessary to consider that objectives like these are often associated with the revolutionary attempt to overthrow "un-Islamic" regimes in the Muslim world. The destruction of "apostate" governments (such as those of Algeria, Indonesia, Morocco, and Pakistan) has been an aim of certain jihadist 
organizations affiliated or allied with the transnational movement of AlQaeda. Tactics such as suicide attacks have been used by Al-Qaeda in the Islamic Maghreb in Algeria, by Jemaah Islamiyya in Indonesia, by the Moroccan Islamic Combatant Group, by the Islamic Movement of Uzbekistan, by Lashkar-e-Jhangvi and Taliban in Pakistan, and by the Al-Shabab Al-Majahedeen in Somalia (Cook 2007; Hafez 2003; Kepel 2005; Gerges 2005; Phares 2005; Riedel 2008).

The immediate goal of Al-Qaeda remains the liberation of all Muslim countries from foreign powers. In this sense, the specificity of Al-Qaeda consists of pan-Islamic nationalism (or supra-nationalism), a mobilization opposing, through extreme terrorist tactics, any action viewed as a threat against the Muslim countries, such as military occupation, exploitation, or political interference (Hegghammer 2007; Pape 2006; Tosini 2007a; 2007b). Although the struggle against "infidel" regimes - the so called "near enemy" (al-adou al-qareeb) - is a crucial purpose of Al-Qaeda, its leaders" priority is to focus on attacking the "far enemy" (al-adou al-baeed) - the US and its allies (Al-Zayyat 2004; Lacroix 2008; Riedel 2008). As stated in The World Islamic Front's Declaration to Wage Jihad against the Jews and Crusaders, issued on 23 February 1998 ,

To kill the Americans and its allies - civilians and military - is an individual duty incumbent upon every Muslim in all countries, in order to liberate the Al-Aqsa Mosque [Jerusalem] and the Holy Mosque [Mecca] from their grip, so that their armies leave all the territory of Islam, defeated, broken, and unable to threaten any Muslim. This is in accordance with the words of God Almighty: '[F]ight idolaters at any time, if they first fight you' [2:193]; 'Fight them until there is no more persecution and until worship is devoted to God' [8:39]. (Bin Laden et al. 1998)

The occupation of Iraq has been viewed by Al-Qaeda as one of the most important opportunities for damaging its number one enemy (the US) and representing itself as the liberator of the territory of Islam through a local, affiliated group. This is AQI, which has emerged from the metamorphosis of Al-Tawhid Wal-Jihad (Monotheism and Jihad), a jihadist movement established in the 1990s by Al-Zarqawi (the first leader of AQI until he was killed by an American counterinsurgency operation in June 2006). Its original purpose was to overthrow the political regimes in the Middle East and set up new states based on Islamic law (Milelli 2008; Napoleoni 2005; Riedel 2008:Chapter 5). In an attempt to capitalize on the political opportunities of the imminent Anglo-American invasion of Iraq, Al-Zarqawi and his followers arrived in Northern Iraq in 2002, where they established training camps in alliance with local Islam- 
ist organizations, such as Ansar Al-Islam (Partisans of Islam) (cf. Riedel 2008:Chapter 5). After the invasion, Al-Zarqawi's network became the ideal candidate for exporting Al-Qaeda's transnational campaign to Iraq. In October 2004, probably following a series of negotiations involving the central leaders of Al-Qaeda, Al-Zarqawi publicly pledged allegiance to Bin Laden and changed the name of his organization to AQI. Osama Bin Laden issued a statement in December 2004 confirming Al-Zarqawi as the "emir" of this new group (Cordesman 2008:113). In a letter of July 2005 attributed to Ayman Al-Zawahiri and addressed to Al-Zarqawi, AlZawahiri provides the synthesis of all major objectives of Al-Qaeda's transnational movement, with special reference to AQI:

[W]e must think for a long time about our next steps and how we want to attain it, and it is my humble opinion that the jihad in Iraq requires several incremental goals:

The first stage: Expel the American from Iraq.

The second stage: Establish an Islamic authority or emirate, then develop it and support it until it achieves the level of a caliphate-over as much territory as you can to spread its power in Iraq, i.e. in Sunni areas, is in order to fill the void stemming from the departure of the Americans, immediately upon their exit and before un-Islamic forces attempt to fill this void, whether those the Americans will leave behind them, or those among the un-Islamic forces who will try to jump at taking power....

The third stage: Extend the jihad wave to the secular countries neighbouring Iraq.

The fourth stage: It may coincide with what came before: the clash with Israel, because Israel was established only to challenge any new Islamic entity. (cited in Cordesman 2008:157)

Declarations like these are examples of Al-Qaeda's framing of the "resistance" against the US-led occupation in terms of a global struggle for the liberation of Muslim lands from un-Islamic forces (pan-Islamic nationalism). They constitute not only statements of the main and nonnegotiable objective of a vanguard embodied by Al-Qaeda's elite members (such as Bin Laden, Al-Zawahiri, and Al-Zarqawi). They are also part of a propaganda instrument used by Al-Qaeda to attract a number of young Muslims mentioned above, who, like the old generation fighting in Afghanistan in the 1980s, consider the jihad in defence of the Islamic nation as the supreme duty of all pious Muslims.

Call for such a jihad is tantamount to confronting unrivalled military superpowers, particularly in the case of the US army. Under such cir- 
cumstances, the only kind of combat consists of conducting warfare that should bypass any direct fighting with the enemy and take advantage of its weakness and, in doing so, restore the balance of coercion between insurgents and their enemy as much as possible. Since 2003 a high percentage of the targets of suicide bombers in Iraq have been new Iraqi forces and civilians, particularly Shiites. Here, AQI takes old arguments supporting the use of "unconventional" tactics to an extreme. Consider, for example, the well known justification by the spiritual leader of Hezbollah, Sayyid Muhammad Husayn Fadlallah, for certain types of suicide attacks executed by the Lebanese organizations in the 1980s:

When a conflict breaks out between oppressed nations and imperialism, or between two hostile governments, the parties to the conflict seek ways to complete the elements of their power and to neutralize the weapons used by the other side. For example, the oppressed nations do not have the technology and destructive weapons America and Europe have. They must thus fight with special means of their own.... [W]e recognize the right of nations to use every unconventional method to fight these aggressor nations, and do not regard what oppressed Muslims of the world do with primitive and unconventional means to confront aggressor powers as terrorism. We view this as religiously lawful warfare against the world's imperialist and domineering powers. (cited in Kramer 1998:144-145)

From a purely strategic standpoint, terrorist methods against civilians in Iraq have been partly an attempt to compensate for the difference in power between the Iraqi insurgents and the US-led forces. Therefore, to account for these attacks it is necessary to first pay attention to the asymmetric nature of the fighting between AQI and the occupying forces:

Asymmetries in warfare refer to imbalances between opposing forces. These may be differences in numbers of soldiers, equipment, firepower, morale, tactics, values, or other factors. Guerrilla warfare, occurring between lightly armed partisans and a conventional army, is an example of asymmetrical warfare. Terrorist tactics, such as hijackings and suicide bombings, are also considered to be asymmetrical, both because they tend to involve a smaller, weaker group attacking a stronger one and because attacks on civilians are by definition one-way warfare. (Kushner 2003:54; see also Thornton 2007)

As far as the Iraqi insurgency is concerned, this imbalance has become more acute. Insurgent attacks, including suicide attacks, against coalition forces have become difficult because of American soldiers' increased efficacy in defending themselves from any kind of tactics, particularly since 2004 (Hafez 2007:Chapter 3). In this context, violence against the population can be used as an alternative to military confron- 
tation to put pressure on occupying forces and their puppet regime. Insurgents' use of terrorism aims not only at delegitimizing authority by creating a condition of chaos and insecurity while leading counterinsurgency to take reprisals involving the population. Terrorist violence also aims at deterring Iraqi civilians - especially those viewed as potential collaborators, in particular, if not exclusively, the Shiites - from any compliance with incumbents. This corresponds to a specific rational choice of armed organizations. Using unconventional methods, including suicide bombings against civilians, instead of fighting the enemy directly, is part of their strategic gamble. As stated by the US Army-Marine Corps' 2007 Counterinsurgency Field Manual,

Insurgents are by nature asymmetric threat. They do not use terrorist and guerrilla tactics because they are cowards afraid of a "fair fight": insurgents use these tactics because they are the best means available to achieve the insurgency's goals. Terrorist and guerrilla attacks are usually planned to achieve the greatest political and information impact with the lowest amount of risk to insurgents.... Terrorist tactics employ violence primarily against non-combatants. Terror attacks generally require fewer personnel than guerrilla warfare or conventional warfare. They allow insurgents greater security and have relatively low support requirements.... Insurgents choose targets that produce the maximum information and political effects.... Insurgents using guerrilla tactics usually avoid decisive confrontation unless they know they can win. Instead they focus on harassing counterinsurgents. As with terrorist tactics, guerrilla tactics are neither mindless nor random.... The goal is not to militarily defeat counterinsurgency forces but outlast them while building popular support for the insurgency. (US Army-Marine Corps 2007:109)

Iraqi terrorist attacks, combined with the continuation of jihad in other contexts (such as the 2004 Madrid train bombings, the 2005 London underground suicide attacks, and terrorist plots such as the 2006 London transatlantic multiple attack and the 2007 Glasgow airport bombing), constitute the extreme example of asymmetric fighting. Modern forms of asymmetric warfare began to be systematically organized with Mao Tse Tung's guerrillas. One of the most important aspects was the change in methods and rationale of combat. Rather than coerce the enemy through overt fighting, all tactics were selected to drain the enemy's will to fight. The Viet Cong against the US and the Afghans against the Soviet Union also followed this path. More recent evolution in armed organizations, which Donald J. Reed (2008) identifies as a new generation of warfare, has radicalized the nature of asymmetric fighting. The Al-Qaeda network, which includes AQI and a number of terrorist cells inspired by its pan-Islamic nationalism, represent a particularly clear example. 
In Al-Qaeda's modus operandi, the militants' battlefield is everywhere. Warfare is taken away from the monopoly of states, and becomes the business of nonstate organizations, small cells, and even lone bombers (see Kirby 2007). At the same time, Al-Qaeda's strategy considers all means as legitimate combat methods, including mass casualty attacks on gatherings of unarmed civilians. As a result, all boundaries between combatants and noncombatants vanish. For jihadists, rules of international law, central to the system of international relations since the 1648 Westphalia Peace Agreement, have no binding effect on their behaviour. Such rules exist only for their enemies. Terrorists exploit this asymmetry to gain power by deliberately using violence against defenceless civilians. As Reed notes, "the weak can defeat the strong through ruthless unconventional methods, and the first rule of unrestricted warfare is that there are no rules, with nothing forbidden" (Reed 2008:716; see also Kaldor 2006; Liang and Xiangsui 2002; Münkler 2005). Given such a general tendency of using unconventional and terrorist tactics, the section "The Instrumental Rationality of Suicide Attacks examines the rationale underlying the specific case of suicide attacks on civilians used by the Iraqi Sunni insurgency, paying attention to their technical, emotional, and symbolic advantages, compared with other terrorist tactics. Before discussing this topic, we have to focus on additional factors, beyond the asymmetric nature of Al-Qaeda's fighting, to clarify insurgents' reasons for targeting a specific part of the Iraqi civilians (the Shiites) using a variety of terrorist methods, both nonsuicide bombings and suicide missions.

\section{Al-Qaeda's Vigilantism against the Shittes}

We now explore the second question posed in this paper: why AQI and its allies have targeted civilians within (in particular, if not exclusively) the Shiite population, ${ }^{8}$ often by launching mass casualty attacks. Our hypothesis is that explanations of AQI's terrorism against the Shiites that rely exclusively on AQI's asymmetric warfare are insufficient. A more comprehensive analysis requires considering another crucial feature of AQI's strategy: Sunni vigilantism against the Shiites. For AQI and other Sunni extremists, nationalist objectives against foreign occupation and revolutionary campaigns against regimes in the Muslim world are often linked to sectarian activities against the Shiites.

8. As mentioned above, Sunnis, too, were attacked, particularly members and tribal leaders of those militias taking part in the Awakening movement allied with the Americans against AQI and other Islamists. 
This constitutes a frequent element accompanying several Sunni armed groups' terrorist campaigns around the world (at least since the 1980s). The most important event responsible for a long period of sectarian strife was the Shiite awakening following Khomeini's revolution. As with the mobilization of Islamic fundamentalism during the 1960s against the secular Arab nationalism, Saudi Arabia in particular used the weapon of Sunni fundamentalism to oppose Shiite power. Apart from funding universities, schools, mosques, and research institutions, the House of Saud and other countries regularly sponsored a number of Sunni organizations across the Muslim world, inciting a sectarian war. As a result, particularly in the 1990s, a wave of radicalism hit central Asia and the Caucasus. Another case is the Taliban, which grew under the wing of Pakistan exploiting the traditional Pashtun opposition to Shiites. The same can be said of anti-Shiite organizations such as the Sipah-eSahaba and Lashkar-e-Jhangvi, which today also maintain close connections with the Taliban and other Islamist organizations such as Jaishe-Muhammad. To some extent, they are all groups linked to Al-Qaeda before and after the US-led destruction of the Taliban regime following 9/11. As noted by Vali Nasr (2006:167),

[t]here are organizational as well as ideological ties that bind Sunni sectarians, Arab and Asian alike, with Sunni Arab extremists. While outside the Muslim world the violent anti-Westernism of the Taliban and Al-Qaeda appears most prominent, there can be no question that intense hatred of Shias and Shiism is an important motive for both these Sunni terror groups.

From this perspective, it becomes evident that the American and British occupation of Iraq has been opposed not only because of the invasion of a Muslim land, but also for reasons stemming from relations between Sunnis and Shiites. Since the fall of Saddam Hussein, attacks by AQI and other Sunni extremists have aimed to end foreign political influence and confront what that influence makes possible - the emergent power of the Shiites (Cordesman 2008; Hafez 2007; Moghadam 2008; Nasr 2006). Iraqi Shiites, in turn, are viewed as enemies not only because of their alliance with occupying forces (with the exception of some Shiite militias such as Moqtada Al-Sadr's Mahdi Army). They are also enemies because their position in the post-2003 Iraqi regime represents a source of humiliation for the Sunnis, and a challenge to their present and future political and religious status. A string of provisions following the 2003 invasion gave the Iraqi Shiites a new, unprecedented power and took it away from the Sunni hegemony. Apart from the military value of targeting the new Iraqi police and security forces according to the logic 
of asymmetric warfare, the relentlessness of Sunni insurgents' attacks (including suicide attacks) on unarmed Shiites can partly be explained by Sunnis' special (sectarian) focus on Shiite challenges to their power. Sunni terrorism has targeted the Shiites in different contexts, killing construction workers, clerics, community leaders, government officials, pilgrims, as well as men, women, and children at work, at play, at prayers, and in markets, hospitals, and offices, and on streets everywhere: for example, on 2 March 2004, at a Moslem festival parade in Karbala (98171 deaths) and on 16 July 2005, at the Shiite mosque of Al-Musayyib (nearly 100 deaths). These attacks are aimed not only to cause the US-led occupation to fail, but also to intimidate the Shiites and to impede them from dominating the new regime.

This aspect of AQI's campaign is also crucial to understanding the indiscriminate modality of its terrorist attacks aimed at the Shiite population. Attacks on civilians by insurgents in civil wars are part of a specific strategy to coerce incumbents. Indiscriminate attacks, in particular, can be associated with political circumstances under which insurgents lack adequate territorial control and, consequently, cannot collect sufficient information to launch selective attacks (Kalyvas 2006; 2008). The hypothesis presented here is that a more comprehensive explanation of certain cases of indiscriminate violence also requires examining ideological or religious perceptions of targets by insurgents. In these cases, ethnic or religious cleavages continue to be significant factors lifting moral constraints to indiscriminate attacks, instead of selective violence, on civilians of those ethnic or religious communities viewed as a threat in themselves, besides being allied with incumbents (on the role of religious difference as facilitating factor of suicide terrorism, cf. Pape 2006).

Based on this premise, the theory presented here is that AQI's suicide campaign targeting Iraqi Shiites is inspired not only by certain calculations which are typical of asymmetric warfare strategies, such as the use of attacks on civilians aimed at coercing certain occupying forces. This campaign is also a form of vigilante terrorism against members of a specific community or category, the Shiites (cf. Goodwin 2006b). According to Rosenbaum and Sedenberg (1974:542), "when individuals or groups identifying with the established order defend that order by resorting to means that violate ... formal boundaries, they can be usefully classified as vigilantes." Not all vigilante acts are violent and/or terrorist tactics, but certain forms are clearly violent and bloody. This is true of the Iraqi scenario, where a part of Sunni insurgents' operations, especially of AQI, have probably been motivated not only by the objective of deterring the Shiites from supporting the Anglo-American occupation, 
but also by the urgency of restoring the Sunni minority's power in Iraq and defending the Sunnis' dominant position in the Muslim world.

Vigilante positions are evident in the view expressed by AQI's elite members. Particularly for al-Zarqawi, Iraqi insurgency is contingent on both the pan-Islamic nationalism and an "all-out war" against the Shiites, as declared in a letter of February 2004:

These [the Shiites] in our opinion are the key to change. I mean that targeting and hitting them in [their] religious, political, and military depth will provoke them to show the Sunnis their rabies ... and bare the teeth of the hidden rancor working in their breasts. If we succeed in dragging them into the arena of sectarian war, it will become possible to awaken the inattentive Sunnis as they feel imminent danger and annihilating death at the hands of these Sabeans.... Most of the Sunnis are aware of the danger of these people ... and fear the consequences of empowering them.... This matter, with the anticipated awakening of the slumberer and rousing of the sleeper, also includes neutralizing these [Shiite] people and pulling out their teeth before the inevitable battle, along with the anticipated incitement of the wrath of the people against the Americans, who brought destruction and were the reason for this miasma.... The solution that we see, and God the Exalted knows better, is for us to drag the Shiites into the battle because this is the only way to prolong the fighting between us and the infidels. (Al-Zarqawi 2004; see also Kepel and Milelli 2008).

In the same letter, Al-Zarqawi combines different arguments based on a plurality of political and religious ideological elements, referring simultaneously to the loss of power that had affected Sunnis in Iraq since the US-led invasion and to the Sunni-Shiite conflict over centuries. Hence, in Al-Zarqawi's statements a mixture of opposition to foreign powers and anti-Shiite sectarianism motivates the Iraqi insurgency. For Al-Zarqawi, reasons for attacking the Shiites also include theological motives, as demonstrated by citations of Ibn Taymiya's anti-Shiite fatawa, as well as a number of Sunni accusations against the Shiites because of their unacceptable religious view. Following the diagnosis expressed in his letter of 2004, in September 2005 Al-Zarqawi radicalized AQI's opposition to the Shiites and declared total war:

[T] he Al-Qaeda organization in the Land of the Two Rivers has decided: First, since the government of the descendant of Ibn Al-'Alqami and the servant of the Cross, Ibrahim Al-Ja'fari, has declared a total war against the Sunnis in Tel'afar, Ramadi, Al-Qaim, Samarra, and Al-Rawa, under the pretext of restoring rights and eliminating the terrorists, the organization has decided to declare a total war against the Rafidite Shi'ites throughout Iraq, wherever they may be. This is a fitting reward, because you started the aggression.... Second, from now on, whoever is proven 
to belong to the Pagan [National] Guard, to the police, or to the army, or whoever is proven to be a Crusader collaborator or spy - he shall be killed. Furthermore, his house shall either be destroyed or burned down, after the women and children are taken out of it. This is his reward for betraying his religion and his nation, so that he shall serve as a clear lesson and a preventive warning to others.... We warn the tribes that any tribe, party, or association that has been proven to collaborate with the Crusaders and their apostate lackeys - by God, we will target them just like we target the Crusaders, we will eradicate them and disperse them to the winds. There are only two camps - the camp of truth and its followers, and the camp of falsehood and its Shi'ites. You must choose in which of the two trenches you lie. (Al-Zarqawi 2005) ${ }^{9}$

Such sentiments form the second and crucial component (in addition to the call for jihad against un-Islamic occupation) of Al-Qaeda's propaganda machine, which could efficiently rely on a breeding ground of radicalized young Sunni Muslims. Indeed, as reported by Mekhennet and Moss (2008) from Jordan,

[t] he anger among militants in Zarqa, a mostly Sunni city, is now directed at Shiites as much as Americans, reflecting the escalation in hostility between the two branches of Islam since Shiites gained dominance in the new Iraqi government. 'They have traditions that are un-Islamic and they hate the Sunnis,' said Ahmad Khalil Abdelaziz Salah, an imam whose mosque in Zarqa was attended by some of Zarqa's bombers. Asked to name his targets, Abu Ibrahim [a would-be suicide bomber] said: 'First, the Shiites. Second, the Americans. Third, anywhere in the world where Islam is threatened'." (cited in Mekhennet and Moss 2008)

This clarifies the logic underlying a series of suicide attacks - such as several bombings on 23 November 2006, targeting two markets and other shopping precincts in Sadr City (about 200 deaths); a truck bomb on 3 February 2007, in a crowded market in the Shiite district of Sadriyah in Baghdad (about 135 deaths); a suicide attack on 27 March 2007, aimed at Shiite civilians in Tall Afar (about 150 deaths); and a car bomb on 28 April 2007, targeting the Imam Abbas mausoleum in Karbala (about 70 deaths). ${ }^{10}$

9. As noted by Nasr, "He [Al-Zarqawi] qualified the 'war on Shia' to 'war on all collaborators with the occupation.'... It put the burden on Shias to prove that they are not 'collaborators,' which they could do only by joining the insurgency and succumbing to Sunni domination. Giving the attacks on Shias a nationalist cover thus served as the mantra for sectarian politics in Iraq" (Nasr 2006:209-210).

10. As noted by George Michael, "[e]ssentially, Zarqawi pursued a dual strategy in Iraq; first to drive out the coalition forces, and second to foment a civil war between the Shi'a and Sunni populations. According to Saif al-Adel, a leader of the military wing of al-Qaeda, Zarqawi was greatly inspired by the twelfth century Arab sultan, Nur al- 
In sum, in analyzing AQI's suicide terrorism campaign several factors must be considered. Attacking the Shiite population is a deliberate aim at: creating a condition of terror and insecurity which could delegitimize both US authority and that of the new Iraqi regime; deterring Shiites from supporting the US and the new government; causing Shiite reprisals against the Sunnis to provoke a civil war, allowing the Sunni minority to support, and take part in, the insurgency as a defence against the Shiites; and, finally, using vigilante activities to defend the status of Sunnis against the growing power of Shiites. This also reverberates through the Sunni-Shiite relations in other contexts, such as in Pakistan, where Sunni extremists such as Lashkar-e-Jhangvi and other Al-Qaeda allies view the Shiites as both instruments of American aggression of Muslim countries such as Afghanistan and Iraq and a threat to Sunni power. In this respect, our data on suicide attacks in Pakistan also show incidents in which main targets are clearly the Shiite population and/ or Shiite political leaders. This suggests an inextricable link in Sunni's terrorist campaigns between pan-Islamic nationalism opposed to foreign occupation and political interference in Islamic affairs, on one hand, and a persistent, deep hate towards the Shiites, on the other (see also Nasr 2006:Chapter 5).

\section{The Instrumental Rationality of Suicide Attacks}

Finally, the issue of why AQI and other Iraqi insurgents have adopted suicide attacks instead of other terrorist tactics against soft targets like the Shiite population must be addressed. The use of terrorist tactics is associated to some extent with an existing imbalance of power, that is, a military asymmetry between armed groups in terms of resources and combatants (Boyns and Ballard 2004; Pape 2006). This suggests resorting to tactics with a presumed higher degree of efficiency. Terrorist leaders are rational actors who select combat methods that are expected to provide the desired type and degree of damage to be inflicted on the

Din Zangi, who pursued two missions in life - namely, drive out the Crusaders from Arab lands and crush the Shi'a rulers. Zarqawi's campaign against the Shi'a was a divisive issue among the leadership of al-Qaeda. Whereas followers of Wahhabism a puritanical sect of Sunni Islam founded in the eighteenth century - have historically persecuted Shi'ia Muslims, bin Laden has sought to bridge the gap between the two denominations and has called for an Islamic united front against the United States and Israel. However, Zarqawi was vehemently opposed to forging a common front with the Shi'a under the banner of Iraqi nationalism. Rather, he preferred to drive a wedge between the Shi'a and Sunni populations and thus foster a sectarian Sunni, rather than a more secular nationalist, character for the insurgency. What is more, Zarqawi feared that a secularly inspired insurgency would fail to attract the foreign jihadists motivated by religious zeal." (Michael 2007) 
enemy, relative to their costs, in terms of a variety of resources (including militants) used for military operations (Crenshaw 1998; della Porta 1995; Kalyvas 2006).

Analyzed from this standpoint, the decision to adopt suicide attacks depends on several calculated advantages in comparison to other means. First of all, suicide attacks are selected on the basis of a rational calculation associated with certain military considerations (Ayers 2008; Berman and Laitin 2006; Hoffman 2003; Hoffman and McCormick 2004; Hafez 2007). The most important are: inflicting greatest damage on the enemy using the least number of militants compared with higher casualties in direct and conventional military confrontation; attackers escaping capture and not providing the enemy with any information about terrorist organizations; maximizing the number of victims depending on the attacker's ability to modify their positions; and the minimal costs of attacker training. For example, in his book Knights under the Prophet's Banner (2001), Al-Zawahiri wrote about suicide attacks as follows:

Killing the Americans with a single bullet, a stab, or a device made up of a popular mixture or hitting them with a iron bar is not impossible. Likewise, burning their property with Molotov cocktail is not difficult.

Suicide operations are the most successful in inflicting damage on the opponent and the least costly in terms of casualties among the fundamentalists.

The targets and the type of weapons must be selected carefully to cause damage to the enemy's structure and deter it enough to make it stop its brutality.

Cause the greatest damage on the opponent, no matter how much time and effort these operations take, because this is the language understood by the West. (Al-Zawahiri 2001:200-201)

The "military" characteristics mentioned above are unquestionably important if the aim is to destroy certain hard targets, such as military barracks and vehicles, and other highly defended locations such as police stations and government buildings. This does not explain the use of suicide attacks on soft targets, once it is sufficiently clear that other tactics would obtain the same result of massacring unarmed civilians without the cost of sacrificing militants for executing attacks (Cordesman 2008:652). Using suicide bombers in such circumstances has more to do with the emotional consequences than the technical features. As for other terrorist tactics, AQI's suicide attacks on civilians also aim to terrorize and influence one or more main targets behind their direct targets 
(victims) (Schmid and Jongman 1988). This requires paying attention to terrorist techniques, in general, and suicide terrorism in particular, as forms of political and symbolic communication (cf. Gambetta 2009). The first kind of main targets of this communication is the victims' community, that is the Iraqi Shiite community. For them, there is the intended communicative effect generated by dispatching human bombs instead of simply placing parked car bombs or other timed devices. Indeed, militants able to disguise themselves in public gatherings and willing to blow themselves up are a powerful medium of communication that signals to the victims' community both the insurgents' unpredictability and their determination and commitment to escalate the level of violence. An example of this logic within the global jihad is an Al-Qaeda video of July 2006, in which Shenzaz Tanweer, a British-born suicide bomber involved in the 2005 London attacks, clearly refers to the unshakable resolve of the "martyrs" in defence of the Muslim nation, including Afghanistan and Iraq:

We are $100 \%$ committed to the cause of Islam. We love death the way you love life. I tell all you British citizens to stop your support to your lying British government, and to the so-called "war on terror," and ask yourselves why would thousands of men be willing to give their lives for the cause of Muslims. Allah, in Surat Al-Nisa, says: "What is wrong with you that you fight not in the cause of Allah, and for those weak, ill, cheated, and oppressed, among men, women, and children, whose cry is: 'Our Lord, rescue us from this town whose people are oppressors, and raise for us from among you one who will protect, and raise for us from you one who will help'.'... What you have witnessed now is only the beginning of a series of attacks, which, inshallah, will intensify and continue, until you pull all your troops out of Afghanistan and Iraq, until you stop all financial and military support to the US and Israel, and until you release all Muslim prisoners from Belmarsh and your other concentration camps. And know that if you fail to comply with this, then know that this war will never stop, and that we are ready to give our lives, one hundred times over, for the cause of Islam. You will never experience peace, until our children in Palestine, our mothers and sisters in Kashmir, and our brothers in Afghanistan and Iraq feel peace (Al-Qaeda Film 2006).

Communiqués like this aim at amplifying the terror of bombings. Such a psychological effect is certainly increased by the efficacy of suicide attacks, compared with other tactics, in creating spectacular incidents, as demonstrated by the high average number of fatalities associated with jihadist attacks around the world, including the 2005 London suicide bombings, and particularly by the Iraqi suicide campaign of AQI and other Sunni insurgents (for details about this "technical" feature, 
see Ayers 2008). As a result, such incidents usually attract considerable attention from the mass media: they cannot be ignored. However, what really frightens the enemy is the tactic itself, militants committing suicide (instead of simply manufacturing other explosive devices) after closely approaching their victims to deliberately maximize casualties (Hoffman and McCormick 2004). Under such circumstances, suicide bombers create victims' perceptions of the perpetrators' obvious threat, leading the enemy's population and its armed organizations to retaliate through sectarian attacks. This is true of the Shiite militias' retaliation against the Sunni population in Iraq, as expected by Al-Zarqawi in order to trigger a civil war between the two communities (Cordesman 2008; Fearon 2007; Hashim 2006).

Suicide bombers are also a symbolic medium focusing on at least two other main targets of communication: the community whose interests jihadists want to defend and new recruits (Cook and Allison 2007). Suicide attacks signal to the insurgents' presumed constituency the determination, preparedness for ultimate sacrifice, and identification of militants with its economic, political, and religious objectives. This implicit message is usually accompanied by biographical accounts concerning militants fallen in suicide missions, which make explicit the nobility and zeal of such men and their complete devotion to their "brothers," their people, and their religion. For example, Al-Zawahiri uses the following description to sketch the profile of Tanweer and the other members of the 2005 London commando unit:

What made Shehzad join the camps of Qaeda Al-Jihad was the oppression carried out by the British in Iraq, Afghanistan, and Palestine. He would often talk about Palestine, about the British support of the Jews, and about their clear injustice against the Muslims.... That is why Shehzad joined the camps of Qaeda Al-Jihad, where he spent some time, along with Muhammad Al-Siddiq. Both of them were striving for martyrdom, and were hoping to carry out a martyrdom operation. Both of them were very resolute in this.... They were bonded by a great love, for the sake of Allah.... Allah's mercy upon him [Tanweer], he used to pray all night long, and loved reading the Koran.... He would contemplate what he read in the Koran, and often he would stop at a specific verse and say to his brothers: "Look, this is exactly what is happening today." (Al-Qaeda Film 2006)

On the Iraqi battlefield, too, insurgents produced memories of their fighters to mark their greatness. One example is the following description (which is part of a long series of AQI's biographies titled Distinguished Martyrs) of the righteousness of one of its militants: 
In the Name of Allah, Most Gracious Most Merciful.... Abu al-Hurr alAnsari was a courageous, modest, ambitious man, He was among the Ansaar [native Iraqi fighters] from al-Radwaniyya.... Like millions of others, he heard and saw how Muslims women were being stripped of their dignity, and how the honour of Muslim men was being trampled upon.... Abu al-Hurr cried, yet at the same time, he realized that tears would not redeem the honour that had been taken away from Muslims and their Sheiks. Abu al-Hurr turned to the blessed Quran of Allah and read the verses pertaining to jihad that can be found in almost every chapter.... (Al-Qaeda in Iraq 2006b)

These "hagiographies" are additional illustrations of Islamist groups' rational calculations. They do more than legitimize armed actions and gain support from the Sunni community in Iraq and across the Muslim world. As with the suicide bombers' countless communiqués and last wills prepared and propagandized by Al-Qaeda, they are also an instrument of recruitment. Jihadist organizations resort to a set of beliefs and symbolic representations that normalize suicide and mass casualty attacks against unarmed civilians, frequently framed as martyrdom and acts in the service of a good cause. For example, in a 2006 video, titled Convoy of Martyrs and released by Mujahideen Shura Council, a typical statement praising jihad and martyrdom is made by two Saudi Arabian AQI militants against a background of scenery and songs symbolizing their greatness as combatants in defence of their religion:

My beloved ones everywhere ... anyone who loves Allah should follow this path. I ask my mother and father to be patient. Let them know that their son is in the land of jihad, whether he leaves or dies, he will always be there, living, both now and in the hereafter. We shall meet in paradise. Allah is more merciful than both of you, my dear parents. Allah has called me and he shall protect me and make me achieve martyrdom.... And, O' my brother Hassam, Allahu Akhbar, O' Hassam. I hope you are listening to me right now. I beg you to depart to the land of honour and manhood. Don't just sit there and stay behind, and don't listen to anyone who tries to stop you. Just go and kill the Americans. Just kill them and don't leave any survivors. Allahu Akhbar! Allahu Akhbar! (Al-Qaeda in Iraq 2006c)

Last wills like these have been a powerful communicative channel adopted to justify and encourage any personal disposition to become a fighter (whether motivated by outrage, search for social consideration, political commitment, or religious faith), thanks to the recognition of their noble role and moral status in addition to their promised place in heaven. In the same manner as Al-Qaeda's call for jihad in defence of the Islamic nation (pan-Islamic nationalism), against un-Islamic oppression 
and in the battle against the Shiites, all representations of militancy and suicide missions in terms of martyrdom constitute another, fundamental component of the propaganda machine adopted by Al-Qaeda's elite members. They are messages that incite any Muslim to witness his faith while serving his God and his religious community, thereby becoming a hero, a martyr. In addition to the other components to be found in AlQaeda's political and religious rhetoric, such messages have been able to motivate a number of young fighters from the Middle East, who, like veterans of anti-Soviet Afghan jihad in the 1980s, perceived their sacrifice for their religion as their greatest duty. Like other propaganda tools used by armed organizations, symbolic features also show a double nature of suicide missions. On one hand, they are clearly selected by insurgents in accordance to their rational calculations to increase consensus from the Sunni community and attract potential militants as bombers by emphasizing their status of heroes and martyrs. On the other hand, representations of militants as martyrs imply that the efficacy of this propaganda in attracting new attackers depends on the existence among certain young Muslims of a real devotion to specific ideals such as jihad and martyrdom, which are motivational factors other than rational calculations.

In sum, in accounting for the tactical reasons behind the use of suicide attacks, among other terrorist tactics, it is necessary to distinguish at least three main calculations (made by elite members): their military advantages in causing direct damage on the enemy's forces and staging spectacular attacks; their emotional impact on the enemy's constituency due to signalling strength, unpredictability, and resolve; and their symbolic influence on the armed organization's constituencies and potential militants to be recruited as bombers, who view themselves as pious Muslims and martyrs because of their sacrifice in the path of their God and for a superior cause.

\section{Conclusions}

This paper presents an analysis of the suicide campaign conducted by the Iraqi Sunni insurgency since the 2003 US-led invasion. The main issues are why only certain armed organizations, particularly AQI and its allies, have mounted a terrorist campaign in which they have targeted civilians, particularly the Shiite population, instead of occupying forces, and why they have done so by perpetrating suicide attacks instead of using other tactics. As with all cases of insurgency, a series of political and social opportunities exploited by the Sunni armed groups as a precondition for launching their terrorist campaign must be examined. The same 
can be said of their capacity for recruiting militants, including volunteers for suicide missions. However, to account for the distinctive features of AQI's campaign, three elements are emphasized: the radical opposition of AQI and its allies with respect to the new political regime established by the Anglo-American occupation, combined with the highly asymmetric nature of the confrontation between $\mathrm{AQI}$ and the occupying forces; AQI's vigilantism against the Shiites; and, finally, the presumed efficiency of suicide attacks in terms of their military, psychological, and symbolic advantages.

\section{REFERENCES}

Al-Qaeda Film. 2006. Al-Qaeda Film on the First Anniversary of the London Bombings. Middle East Media Research Institute, July 8, http://www. memritv.org/clip/en/1186.htm (Accessed September 10, 2006).

Al-Qaeda in Iraq. 2006a. Footage of Saudi Terrorist Abu Mu'awiya Al-Shimali. Middle East Media Research Institute, February 13, http://www.memritv. org/clip/en/1037.htm (Accessed February 20, 2008).

2006b. Biographies of Al-Qaeda's "Distinguished Martyrs" in Mesopotamia (Abu Musab al-Zarqawi), edited by E. Kohlmann. Globalterroralert, March, http://www.globalterroralert.com/pdf/0306/zarqawi0306. pdf (Accessed February 25, 2008).

2006c. Al-Qaida's "Convoy of Martyrs" in Iraq, edited by E. Kohlmann. Counterterrorism Blog, February 24, http://counterterrorismblog. org/2007/02/new video alqaidas convoy of m.php (Accessed February 6,2008$)$.

Al-Zarqawi, Abu Musab. 2004. February 2004 Coalition Provisional Authority English translation of terrorist Musab Al-Zarqawi letter. U.S. Department of State, http://2001-2009.state.gov/p/nea/rls/31694.htm (Accessed January 20,2008 ).

2005. Leader of Al-Qaeda in Iraq Abu Mus'ab Al-Zarqawi declares "total war" on Shiites. Middle East Media Research Institute, September 14, http://www.memritv.org/clip/en/853.htm (Accessed February 20, 2008).

Al-Zayyat, Montasser. 2004. The Road to Al-Qaeda: The Story of Bin Laden's Right-Hand Man. London: Pluto Press.

Al-Zawahiri, Ayman. 2001. Knights under the Prophet's banner. Pp. 19-225 in L. Mansfield, ed., His Own Words: The Writings of Dr. Ayman Al-Zawahiri. TLG Publications. http://www.lauramansfield.com (Accessed: May 20, 2007)

Ayers, Nick. 2008. Ghost martyrs in Iraq: An assessment of the applicability of rationalist models to explain suicide attacks in Iraq. Studies in Conflict and Terrorism 31(9):856-882. 
Baram, Amatzia. 2005. Who are the insurgents? Sunni Arab Rebels in Iraq. United States Institute of Peace, Report April 2005, http://www.usip.org/ pubs/specialreports/sr134.pdf (Accessed January 20, 2008).

Berman, Eli and David D. Laitin. 2006. Rational martyrs vs. hard targets: Theory and evidence on suicide attacks. University of Chicago Department of Economics, http://economics.uchicago.edu/download/RatMartyrs6.pdf (Accessed December 20, 2008).

Bin Laden, Osama. 1996 [2005]. A declaration of jihad against the Americans occupying the land of the two holy places. Pp. 23-30 in B. Lawrence, ed., Messages to the World. The Statements of Osama Bin Laden. New York: Verso.

2006 [2007]. O, People of Islam. Pp. 111-148 in L. Mansfield, ed., AlQaeda 2006 Yearbook: The 2006 Messages from Al-Qaeda Leadership. TGL Publications. http://www.lauramansfield.com (Accessed: April 20, 2008)

Bin Laden, Osama, Ayman Al-Zawahiri, Abu-Yasir Rifai Ahmad Taha, Mir Hamzah and Fazlur Rahman. 1998 [2005]. The world Islamic front Jihad against Jews and crusaders. Pp. 58-62 in B. Lawrence, ed., Messages to the World. The Statements of Osama Bin Laden. New York: Verso.

Bloom, Mia. 2005. Dying to Kill. New York: Columbia University Press.

Boudon, Raymond. 2003. Beyond rational choice theory. Annual Review of Sociology 29:1-21.

2007. Essais sur la théorie générale de la rationalité, Paris: PUF.

Boyns, David and James D. Ballard. 2004. Developing a sociological theory for the empirical understanding of terrorism. American Sociologist 35(2):526.

Brym, Robert J. 2008. Religion, politics, and suicide bombing: An interpretative essay. Canadian Journal of Sociology 33(1):89-108.

2009. Suicide bombers: Beyond cultural dopes and rational fools. In M. Cherkaoui and P. Hamilton, eds., Raymond Boudon: A Life in Sociology. Oxford: Bardwell Press.

Campanini, Massimo. 2008. I sunniti. Bologna: il Mulino.

Campanini, Massimo and Karim Mezran. 2007. Arcipelago Islam. Roma-Bari: Laterza.

Chehad, Zaki. 2005. Inside the Resistance: The Iraqi Insurgency and the Future of the Middle East. New York: Nation Books.

Combating Terrorism Center (CTC). 2007. Al-Qaeda's foreign fighters in Iraq. http://ctc.usma.edu/harmony/pdf/CTCForeignFighter.19.Dec07.pdf (Accessed December 20, 2008).

2008. Bombers, bank accounts, and bleedout: Al-Qa'ida's road in and out of Iraq. http://ctc.usma.edu/harmony/pdf/Sinjar 2 July 23.pdf (Accessed January 15, 2009). 
Cook, David. 2005. Understanding Jihad. Berkeley: University of California Press.

Cook, David and Olivia Allison. 2007. Understanding and Addressing Suicide Attacks. Westport, CT: Praeger.

Cook, Steven A. 2007. Ruling but not Governing: The Military and Political Development in Egypt, Algeria, and Turkey. Baltimore: Johns Hopkins University Press.

Cordesman, Anthony H. 2008. Iraq's Insurgency and the Road to Civil Conflict. Westport, CT: Praeger.

Crenshaw, Marta. 1998. The logic of terrorism: Terrorist behavior as a product of strategic choice. Pp. 7-24 in W. Reich, ed., Origins of Terrorism. Washington DC: Woodrow Wilson Center Press.

della Porta, Donatella. 1995. Social Movements, Political Violence and the State: A Comparative Analysis of Italy and Germany. Cambridge: Cambridge University Press.

Durkheim, Émile. 2006. Suicide. New York: The Free Press.

Elster, Jon. 2006. Motivations and beliefs in suicide missions. Pp. 233-258 in D. Gambetta, ed., Making Sense of Suicide Missions. Oxford: Oxford University Press.

Esposito, John. 2002. Unholy War. Oxford: Oxford University Press.

Fearon, James. 2007. Iraq's civil war. Foreign Affairs, March/April, http://www. foreignaffairs.com/articles/62443/james-d-fearon/iraqs-civil-war (Accessed May 15, 2007).

Galbraith, Peter W. 2008. Unintended Consequences: How War in Iraq Strengthened America's Enemies. New York: Simon \& Schuster.

Gambetta, Diego. 2006. Epilogue to the paperback edition. Pp. 301-333 in D. Gambetta, ed., Making Sense of Suicide Missions. Oxford: Oxford University Press.

2009. Codes of the Underworld: How Criminals Communicate. Princeton, NJ: Princeton University Press.

Gerges, Fawaz A. 2005. The Far Enemy: Why Jihad Went Global. Cambridge: Cambridge University Press.

Goodwin, Jeff. 2001. No Other Way Out: State and Revolutionary Movements, 1945-1991. Cambridge: Cambridge University Press.

2006a. What we really know about (suicide) terrorism. Sociological Forum 21(2):315-330.

2006b. A theory of the categorical terrorism. Social Forces 84(4):20272046.

González, Roberto J. 2009. Going 'tribal': Notes on pacification in the 21st century. Anthropology Today 25(2):15-19

Gunaratna, Rohan. 2002. Inside Al-Qaeda. New York: Penguin. 
Guolo, Renzo. 2002. Il fondamentalismo islamico. Roma-Bari: Laterza.

Guolo, Renzo and Enzo Pace. 1998. I fondamentalismi. Roma-Bari: Laterza.

Hafez, Mohammed. 2003. Why Muslims Rebel. London: Lynne Rienner Publisher.

2007. Suicide Bombers in Iraq. Washington DC: United States Institute of Peace Press.

Hashim, Ahmed S. 2006. Insurgency and Counter-Insurgency in Iraq. Ithaca, NY: Cornell University Press.

2009. Iraq's Sunni Insurgency. London: Routledge.

Hassan, Riaz. 2008. Global rise of suicide terrorism: An overview. Asian Journal of Social Science 36:271-291.

Hegghammer, Thomas. 2007. Saudi militants in Iraq. Norwegian Defence Research Establishment, February, http://rapporter.ffi.no/rapporter/2006/03875.pdf (Accessed January 20, 2008).

Hoffman, Bruce. 2003. The logic of suicide terrorism. The Atlantic Monthly, June, http://www.theatlantic.com/doc/200306/hoffman (Accessed March $8,2006)$.

Hoffman, Bruce and Gordon H. McCormick. 2004. Terrorism, signaling, and suicide attack. Studies in Conflict and Terrorism 27(4):243-281.

Hopgood, Stephen. 2006. Tamil Tigers 1987-2002. Pp. 43-76 in D. Gambetta, ed., Making Sense of Suicide Missions. Oxford: Oxford University Press.

International Crisis Group (ICG). 2006a. The next Iraq war? Sectarianism and civil conflict. International Crisis Group, Middle East Report No. 52, February 27, http://www.crisisgroup.org/home/index.cfm?id=3980\&l=1 (Accessed February 8, 2008).

2006b. In their own words: Reading the Iraqi insurgency. International Crisis Group, Middle East Report No. 50, February 15, http://www. crisisgroup.org/home/index.cfm?id=3953\&l=1 (Accessed February 5, 2008).

Jackson, Jeffrey W. 2006. Military Intervention in Identity Group Conflicts: A Social Movement Theory Perspective on the Sunni Insurgency in Iraq. Monterey, CA: Naval Postgraduate School.

Kaldor, Mary. 2006. New and Old Wars. Cambridge: Polity.

Kalyvas, Stathis N. 2006. The Logic of Violence in Civil War. Cambridge: Cambridge University Press. 2008. Promises and pitfalls of an emerging research program: The microdynamics of civil war. Pp. 397-421 in S.N. Kalyvas, ed., Order, Conflict, and Violence. Cambridge: Cambridge University Press.

Karam, Salam. 2007. The multi-faced Sunni insurgency. Civil Wars 9(1):87-105.

Kepel, Gilles. 2005. Jihad: The Trial of Political Islam. Cambridge, MA: Harvard University Press. 
Kepel, Gilles and Jean-Pierre Milelli, eds. 2008. Al-Qaeda in Its Own Words. Cambridge, MA: Harvard University Press.

Khosrokhavar, Farhad. 2005. Suicide Bombers. London: Pluto Press.

Kirby, Aidan. 2007. The London bombers as "self-starters." Studies in Conflict and Terrorism 30(5):415-428.

Kohlmann, Evan. 2007. The state of the Sunni insurgency in Iraq. NEFA Foundation, Special Report, August http://www.nefafoundation.org/miscellaneous/iraqreport0807.pdf (Accessed August 30, 2007).

Kramer, Martin. 1998. The moral logic of Hizballah. Pp. 131-157 W. Reich, ed., in Origins of Terrorism. Washington DC: Woodrow Wilson Center Press.

Kushner, Harvey. W. 2003. Asymmetrical warfare. Pp 54-56 in H.W. Kushner, ed., Encyclopedia of Terrorism. London: Sage.

Lacroix, Stéphan. 2008. Ayman Al-Zawahiri, veteran of Jihad. Pp. 147-170 in G. Kepel and J.-P. Milelli, eds., Al-Qaeda in Its Own Words. Cambridge, MA: Harvard University Press.

Levitt, Matthew. 2006. Hamas: Politics, Charity, and Terrorism in the Service of Jihad. Washington DC: The Washington Institute for Near East Policy.

Liang, Qiao and Wang Xiangsui. 2002. Unrestricted Warfare. Panama City: Pan American Publishing Company.

Mekhennet, Soaud and Michael Moss. 2008. In Jihadist haven, a goal: To kill and die in Iraq. New York Times, April 5.

Michael, George. 2007. The legend and legacy of Abu Musab al-Zarqawi. Defence Studies 7(3):338-357.

Milelli, Jean-Pierre. 2008. Abu Musab Al-Zarqawi, Jihad in "Mesopotamia.” Pp. 237-250 in G. Kepel and J.-P. Milelli, eds., Al-Qaeda in Its Own Words. Cambridge, MA: Harvard University Press.

Moghadam, Assaf. 2008. The Globalization of Martyrdom. Baltimore: Johns Hopkins University Press.

Münkler, Herfried. 2005. The New Wars. Cambridge: Polity.

Nance, Malcom W. 2007. The Terrorists of Iraq. Book Surge Publishing.

Napoleoni, Loretta. 2005. Insurgent Iraq: Al-Zarqawi and the New Generation. New York: Seven Stories Press.

Nasr, Vali. 2006. The Shia Revival. London: W.W. Norton and Company.

Nine Eleven Finding Answers (NEFA) Foundation. 2006. The role of foreign fighters in the Iraqi jihad. NEFA Foundation, May, http://www1.nefafoundation.org/multimedia-original.html (Accessed February 10, 2008).

Obaid, Nawaf and Anthony Cordesman. 2005. Saudi militants In Iraq: Assessment and kingdom's response. Center for Strategic and Inter- 
national Studies. $\quad$ http://www.csis.org/index.php?option=com csis pubs\&task=view\&id=1442 $($ Accessed February 10, 2008).

Paley, Amit R. 2008. Teenage bomber strikes in Anbar. Washington Post, January 21.

Pape, Robert A. 2003. The strategic logic of suicide terrorism. American Political Science Review 97(3):343-361. 2006. Dying to Win. London: Gibson Square Books.

Paz, Reuven. 2005. Arab volunteers killed in Iraq: An analysis. Prism Series of Global Jihad, No. 1/3, March, http://www.e-prism.org/images/PRISM no 1 vol 3 - Arabs killed in Iraq.pdf (Accessed February 10, 2008).

Pedahzur, Ami. 2005. Suicide Terrorism. Cambridge: Polity Press.

Peraino, Kevin. 2008. Destination martyrdom. Newsweek, April 28, http://www. newsweek.com/id/132938 (Accessed April 28, 2008).

Phares, Walid. 2005. Future Jihad. New York: Palgrave.

Ranstorp, Magnus. 1997. Hizb'Allah in Lebanon. New York: Palgrave MacMillan.

Reed, Donald J. 2008. Beyond the war on terror: Into the fifth generation war and conflict. Studies in Conflict and Terrorism 31(8):664-722.

Reuter, Christoph. 2004. My Life is a Weapon: A Modern History of Suicide Bombing. Princeton, NJ: Princeton University Press.

Ricolfi, Luca. 2006. Palestinians, 1981-2003. Pp. 77-130 in D. Gambetta, ed., Making Sense of Suicide Missions. Oxford: Oxford University Press.

Riedel, Bruce. 2008. The Search for Al-Qaeda. Washington DC: Brookings Institution Press.

Robinson, Glenn E. 2007. The battle for Iraq: Islamic insurgencies in comparative perspective. Third World Quarterly 28(2):261-273.

Rosenbaum, Ron H. and Peter C. Sedenberg. 1974. Vigilantism. Comparative Politics 6(4):541-570.

Sageman, Marc. 2004. Understanding Terror Networks. Philadelphia: University of Pennsylvania Press. 2008. Leaderless Jihad. Philadelphia: University of Pennsylvania Press.

Schmid, Alexander P. and Albert J. Jongman. 1988. Political Terrorism. London: Transaction Publishers.

Snow, David A. and Scott C. Byrd. 2007. Ideology, framing processes, and Islamic terrorist movements. Mobilization 12(1):119-136.

Tosini, Domenico. 2007a. Terrorismo e antiterrorismo nel XXI secolo. BariRoma: Laterza.

2007b. Sociology of terrorism and counterterrorism. Sociology Compass 1(2):664-681. 
2009. A sociological understanding of suicide attacks. Theory, Culture and Society 26(4):67-96.

Thornton, Rod. 2007. Asymmetric Warfare. Cambridge: Polity.

US Army - Marine Corps. 2007. Counterinsurgency Field Manual. Chicago and London: The University of Chicago Press.

Wintrobe, Ronald. 2006. Rational Extremism. Cambridge: Cambridge University Press.

Domenico Tosini is Assistant Professor at the University of Trento (Italy). His research is located at the intersection of sociological theory, political sociology and sociology of law, including: asymmetric warfare, insurgency, terrorism, counterinsurgency, counterterrorism, cultural and religious factors, suicide terrorism, Al-Qaeda transnational movement, Sunni insurgency and Al-Qaeda's terrorist campaign in Iraq; the process of radicalization of Al-Qaeda network's militants in Europe. He has authored papers for several journals, including Contemporary Sociology, International Journal of the Sociology of Law, Quaderni di Sociologia, Social Science Information, Sociology Compass, and Theory Culture and Society. He recently published Terrorismo e antiterrorismo nel XXI secolo [Terrorism and Counterterrorism in the Twenty-First Century] (Laterza, 2007) domenico.tosini@unitn.it 